\title{
Misconception on the Authority Abuse of Power in the Law Enforcement against Corruption
}

\author{
Sadjijono $^{1} \&$ Bagus Teguh Santoso ${ }^{1}$ \\ ${ }^{1}$ Faculty of Law, Bhayangkara University, Surabaya, Indonesia \\ Correspondence: Bagus Teguh Santoso, Faculty of Law, Bhayangkara University, Surabaya, Indonesia. E-mail: \\ bagusteguhsantoso@rocketmail.com
}

Received: April 29, 2017

doi:10.5539/ass.v13n9p51
Accepted: July 9, $2017 \quad$ Online Published: August 25, 2017

URL: https://doi.org/10.5539/ass.v13n9p51

\begin{abstract}
Law No. 30/ 2014 on Government Administration brings the strength and the averment on the performance of the governmental functions which include executive, legislative, and juridical in order to provide the public services (bestuurzorg). Such regulation also aims to prevent and to eliminate any kinds of the maladministration done by the government officials/organs in implementing their functions so that good governance can be realized. In implementing their function, the government should rely on the useful performance (doelmatigheid) and the effectiveness (doeltreffenhgeid) according to the norms of each authority. It is a sophism when the 'authority' and/or the 'competence' mentioned under the Law No. 30/ 2014 on Government Administration are defined differently in the letterlijk gramatikal wet without associating those terms with an understanding of bevoegheid in an administrative legal concept. An idea that distinctively defines the term 'competence' as a right and 'authority' as a power is considered as an inconsistent idea, which may cause dualism and distortion in the common law enforcement reffering to the administrative law, particularly related to the concept of the authority abuse of power mentioned under the Law No. 31/ 1999 amended by the Law No. 20/ 2001 on deeds against corruption. As the result, when the notion of 'authority abuse of power' is defined as a right (as mentioned in article 1, subsection 5 jo. article 17, Law No. 30/ 2014 on Government Administration), it will be characterized into the absolute competence of the administrative jurisdiction, and when the notion of 'authority abuse of power' is defined as a power (as mentioned in article 3, Law No. 31/ 1999 on deeds against corruption), it will be characterized into the absolute competence of the corruption-act jurisdiction. Meanwhile, implementing the government's 'competence' and/or 'authority' is characterized into one concept based on the norms of the authority power.
\end{abstract}

Keywords: Bestuurzorg, Rechtsbescherming, Bevoegheid, Preventif, Dualism, Doelmatigheid, Doeltreffenhgeid, Maladministration, Due Process of Law, Rechtstaat

\section{Introduction}

A criminal act of corruption associated with to the abuse of authority is a kind of criminal acts mostly done by the government officials. In a legal doctrine, corruption is similar to "onrechtmatige overheidsdaad" or, the interpreated by Sudikno Mertokusumo $(2014,7)$, it is defined as 'government's maladministration'. Sudikno Mertokusumo cited in his book entitled "Perbuatan Melawan Hukum oleh Pemerintah" comprehensively described the history of government's maladministration which derives from onrechtmatige overheidsdaad by discerning the difference between government's public deeds and private deeds.

Currently, the public policy is interpreated as a key of success for developing countries, hence, the political development in such countries is increasingly interesting to be concerned on since the political processes collaborate with the law-making processes through which may lead to the development, and conversely, the alteration of the law seems to be getting worse and more inconsistent. Either the success or the failure of developing countries depends on their performance in developing their superior policies and is determined by the path of its development. The law instrument is one important means to succeed in a developing country. However, it should be recognized that the law instrument must not be solely led to the social defense and social welfare by applying criminal law. That is, besides relying on the instrument of ansich criminal law, realizing the social defense and the social welfare need other integrated law instruments, such as private law and administrative law, supported by the appropriate public policies. The concept of the democracy applied in a 
government system of Indonesia, as a developing country, is identified as means to create the social defense and the social welfare. However, it should be based on both integrated law instrument and public policy system. It seems that it is not difficult to reach, depending on the commitment of the state's policy makers. People expect that organizing a state/government may always be able to highly touch and to focus on the public interests and any related conditions in order to meet their needs by applying several concrete steps in the form of the welfare insurer (the state acts as provider), the regulator, the entrepreneur, and the umpire. In organizing a state which leads to the social defense and the social welfare under the concept of welfare staat in a developing rechstaat (e.g., Indonesia), the existence of the administrative law is considered as a primary instrument which sets out the democracy and the protection of human rights in a rechstaat.

The public policy established by the government officials is an independent authority (bevoegvrijheid atau freies ermessen) adhered to the public officials and it is defined as a discretion authority, in which the officials are free to act and/or not to act based on their own judgment, but for the sake of public interests. Thus, it indicates that public policy refers to 'a an effective weapons' public officials have. However, public officials should be careful in using that 'weapon' given its dual function as a rescuer and/or a killer of both the goverment and the public.

The public policy, identified as 'an effective weapon', derives from the authority itself adhere to the state officials in implementing their functions. However, some juridical officials who see the maladministration in corruption as a crime without considering any domain of the administrative law implicating on criminal sanctions as mentioned in article 3 Law No. 31/ 1999 jo. Law No. 20/2001 in dealing with the actions against corruption often uses such authority as a criminalization or over-criminalization. From that perspective, juridical officials seem to define the nature of corruption as an extraordinary crime. Thus, the law interpretation and the implementation of law in exclusively seem as if those may override other existing and related legal principles, like overriding the administrative law adhered to the government officials (ambtdrager). Furthermore, Andhi Nirwanto $(2015,17)$ as the deputy attorney general of the Republic of Indonesia asserted such perspective in his writing entitled "Arah Pemberantasan Korupsi Ke Depan Pasca Undang-Undang Administrasi Pemerintahan". He noted:

"The attribution of PTUN as mentioned in Article 21 UU AP, actually does not need to be disputed with TPK judges authority, and particularly considered as the attempt to weaken the efort to erradicate the corruption. When it is carefully studied, the notion of 'abusing the authority' in UU PTPK has a particular definition which differed from 'the abusing competence' which refers to the competence of PTUN, as set under UU AP."

The different definition of both terms, as mentioned in Law No. 30/ 2014 at the general provision of article 1 subsection 5 about the definition of "competence" and article 1 subsection 6 about the definition of "authority" may indeed have distinctive literal meaning when it is interpreted in letterlijk gramatikal wet. However, those two terms have an interrelated meaning when it is seen from the conceptual perspective and the theory of law. Nevertheless, Andhi Nirwanto $(2015,16)$ argued that 'competence' as an official's right had several implications and referred to the domain of the administrative law. He found that it was different from the term 'authority' which was identified as the officials' power to act in public law and not solely have the implication on the administrative law but also impact on the impact on the criminal law. therefore, Andhi Nirwanto asserted that the notion of 'abusing an authority' basically referred to a criminal act (wederrehtelijke) as mentioned in article 2, Law No. 31/ 1999 Jo. Law No. 20/ 2001 on deeds against corruption, not referring to "onrechtmatige overheidsdaad" which relied on general principles of the good governance.

Juridical officials' failure in understanding the element of "authority abuse of power" mentioned in article 3 , Law No. 31/ 1999 Jo. Law No. 20/ 2001 on deeds against the corruption generates the contradictions and inconsistency against the corruption judicial verdict and administrative law, as what we saw in Indosat Media 2 (IM2) issue in which the Supreme Court ruling of the Republic of Indonesia at the criminal department had decided that the director of PT. IM2 was found conducting the corruption, and the contrary, the Supreme Court ruling at national administrative depatment decided that BPKP had no competence to determine the state's financial loss and thus, the result of BPKP investigation used as the basis of article's attribute (bestanddel delict) is considered invalid and has no imperative legal force.

The zest of the criminal law enforcement against corruption is sustainable. However, it should be in harmony with its purposes, and ommit any reasons identifying corruption as an extraordinary crime, thus, the law enforcement should be through extraordinary law enforcement as well, in which the likelihood of abuse of power may happen, or even in contradictated with the concept and purposes of the law enforcement. Such extraordinary law enforcement is designed for particular issues considered as special crimes, such as: corruption, terrorism, 
and drugs. Nevertheless, the implementation of the law often breaks the existing norms, the principles, and the theories of law enforcement, and thus, it is potential to abuse human right. Euphoria on the corruption erradication by juridical officials such as police officers, prosecutors, Corruption Eradication Commission (KPK), judges, and other juridical officials sometimes may break and shift a fundamental principle -from presumption of innocence to presumption of guilty- in enforcing the criminal law. In addition to that, they also often override the principles of due process of law for the sake of enforcing the criminal law, and thus, the officials and/or individuals suspected doing corruption may end as a convict. This may happen due to the lack of the investigation termination for KPK's investigators to stop their investigation in the corruption cases. Hence, although it does not meet a formal condition which requires at least two evidences to judge an individual as a suspect, various legal actions such as criminalization should be enforced. Criminalization is basically in contradiction with both the purposes of law and the essence of law enforcement. It is embarrassing when someone judged as a suspect must be sentenced through criminalization, such as: 2 (two) evidences are collected after someone has been judged as a suspect. Such law enforcement may abuse the fundamental principle of Indonesia criminal law enforcement, presumption of innocence. This, therefore, is seen as "snow ball" and "tools" for the stakeholders of particular function and ruler/entrepreneur's political interest to beat their political and business rivals. In such condition, the juridical officials such as police officers, prosecutors, KPK, judges, and other juridical officials can be seen as agents of interest and/or agents of business, not considered as a fair civil servant and for the sake of justice ("pro justitia") but precisely turns into "pro-power" servants. Therefore, the concept of criminalization is no longer imbued by "the spirit" of criminal law purposes as the social defense and the social welfare, but it tends to lead to the amount of interests beyond the juridical interests, such as overlapping in implementing the criminal law with the administrative dimension.

Enforcing law needs the consistency, that is, the enforcers must be consistent without getting trapped into the mechanism of law in letterlijke (letterlijke wetmatigeheid) as the criteria of law and sentences set by the legislator. Law should be interpreted conceptually related with the scope of law, although an adagium asserted, "lex dura sed tamen scripta". Thus, a comprehensive understanding on law may lead to the goal of law which refers to the fairness. Though the positive law or the plausible law is merely the declaration as Rudolf Stammler $(2014,201)$ argued that "all positive laws, he says; are an attempts at just laws", law should still be interpreted as means to bring justice into the reality and thus, it may lead to the people's welfare. The concept of the law enforcement contains some principles of criminal law which bind the law enforcement offices. Hence, when the law enforcement puts aside the principle of penalization, it may lead the principle of the criminalization and generate over-criminalization in the concrete legal practices. As what the doctrine state that when an individual has been judged as a suspect, he must be sentenced by the court and the principle of presumption of innocence will be applied. With this doctrine, any imposition of fulfilling criminal element, deliberately seeking for public official's fault can be the targeted suspect through various negative ways during the process of the criminal investigation related to public functions. Such actions will ultimately refer to a kind of the criminalization and have negative meaning which may potentially impede the development process of a developing country, such as Indonesia, since public officials may feel afraid of optimally implementing their functions.

Overall, this paper focuses primarily on the concept of 'authority' and 'competence' in the administrative law associated with to Law No. 30/ 2014 on Government Administration. The legal issue discussed here includes: "Does the essence of 'authority abuse of power' and 'competence abuse' have a different concept and theory in the administrative law and in the process of penalizing corruption?" and "Is the legal consequence of 'abusing authority' and 'abusing competence' in administrative law associated with Law No. 30/ 2014 on Government Administration?"

\section{Methods}

This paper applies a doctrinal approach as the method and refers to a normative legal research in the theoretical and the philosophical context. This paper is based on the principles of law. In particular, it aims to examine the concept of an authority abuse of power contained in the criminal/ the common law associated with the principle of competence (bevoegheid) contained in the administrative law, and then we relate the concept with the principles of law applied in the implementation of the regulation.

\section{Discussion}

\subsection{The Concept of authority and competence in Law No. 30/ 2014 about The Government Administration}

Conceptually, "competence" and/or "authority" are the soul of the ambt that adheres to governmental positions (bestuur handeling). The essence of government consists of government organs and functions. In its implementation, the government function needs a legitimate power (rechtskracht). Such legal power derives 
from "competence" and/or "authority" attributed with the rights (rechten) and the obligations (plichten). Thus, the terms of "competence" and/or "authority" are not only identified as the souls of the governmental positions but also as the drivers of government, which consider the country as a moving state (staat in beweging). The government takes control in achieving a welfare state. Therefore, a regulatory instrument is necessary as means of achieving the goals. One of the legal instruments is Law No. 30/ 2014 on Government Administration which has three (3) considerations as follow.

a. Improving the quality of organizing a government;

Government officials and/or institution must refer to the general principles of a good governance and be based on the legitimate regulation in order to use their competence.

b. Solving problems in organizing a government;

The stipulation on the government administration is expected to be useful as solution to provide a legal protection, both for the public and the government officials.

c. Establishing a good governance, particularly for government officials;

Legitimating the regulations on the government administration is considered as a fundamental legal basis for government officials' decisions and/or actions which aim to meet the public needs of law in terms of organizing a government.

Particularly, the definition of competence is set under the article 1 subsection (5) Law No. 30/ 2014 on Government Administration. It defines the term "competence" as government officials' and/or institutions' or other related officials' rights to make decision and/or to organize the government. On the other hand, the term "authority" is set under the article 1 subsection (6), that "authority" is the government officials' and/or institutions' or other related officials' power to act in the public law.

When those two terms ("authority" and/or "competence") are interpreted rigidly by solely refering to one single legal article (letterlijk gramatikal wet), it may generate a contradictory legal consequence between the theory and the concept of bevoegheid in understanding the administrative law. Furthermore, it may also discourage the spirit of Law No. 30/ 2014 on Government Administration as the preventive means of any maladministration conducted by the government officials.

A perspective about the concept of "authority" and/or "competence" is proposed by D. Andi Nirwanto $(2015,17)$ in his paper entitled "Arah Pemberantasan Korupsi Kedepan Pasca Undang-Undang Administrasi Pemerintahan" in IKAHI seminar. He argued:

"Competence as the government officials' right has implications and refers to the administrative law domains. When this competence is not appropriately imposed, the juridical implications of imposing the competence can be annulled or considered invalid (article 30, 31, and $32 \mathrm{UU}$ AP). Given that the competence is categorized into the administrative law domain, the judge of State Administrative Court (PTUN) decides whether or not the officials' competence is legitimate or valid. When the judge of PTUN considers the competence as invalid, the officials' action and/or decision will no longer binding since the action and/or decision is established, thus, any legal consequences that reveal are considered never-exist. However, when the judge of PTUN annuls the official's action and/or decision, the action and/or decision may not be valid since the judgment is established or it keeps valid until the annulment is officially established and will end after the annulment is made. On the contrary, the authority, which is considered as the officials' power, has implication in both the administrative law and the criminal law. Thus, abusing an authority basically refers to criminal act (wederrechtelijke), as mentioned in article 2, Law No. 31/ 1999 Jo. Law No. 20/ 2001 on Eradication of corruption.

Furthermore, D. Andi Nirwanto $(2015,19)$ asserted:

In order to qualify the official's action and/or decision as corruption, it will be considered as corruption when a crime is preceded and followed by bad will (mens rea) from the public official. The official's bad will (mens rea) which colors the discretionary policy he established and lead to the financial loss to the country is a qualified indicator referring to the corruption as set in article 2 and 3 UU PTPK. Following Andi Nirwanto, the concept of a competence abuse in the perspective of the administrative law has its own characteristics which differ from authority abuse in the criminal law that deals with the corruption.

His argument seems incompatible and confusing, given that based on the theory and legal norms set in article 2 and 3 Law No. 31/ 1999 Jo. Law No. 20/ 2001 on Eradication of Corruption, those two terms have definitely different key elements (bestanddeel delict). Article 2 refers to that every individual and action against the law 
which may lead to financial or economy loss to the country, while article 3 refers to every individual and action of abusing an authority, opportunities, or it means that he has functions which may lead financial or economy loss to the country. Based on these, the concept and the theory between these two articles are definitely apparent. Wederrechttelijke set in article 2 is considered as a key element of delict related with the pure concept of the criminal law, while abusing the authority set in article 3, Law No. 31/ 1999 Jo. Law No. 20/ 2001 on Eradication of Corruption is identified as a key element of the delict (bestanddeel delict) in the administrative law dimension. Thus, when both authority and competence are interpreted as two different concepts by providing theorem in letterlijk gramatikalwet against the article 1 subsection (5) Law No. 30/ 2014 on Government Administration in which 'competence' is considered as a right and the provision of article 1 subsection (6) considers 'authority' as a power, the concept of fallacy sophism in law enforcement may exist.

In regard to the context of politic of law, the enactment of Law No. 30/ 2014 on Government Administration constructs a unification of concept over the terms "authority" and "competence" based on the principle of lex posteriori specialis derogat legi priori specialis preference which means as a new specific rule that puts aside the former one, and thus, the exclusive meaning of the new rule is used as the basis of interpreting the difference of those two terms, although the element of competence abuse is implicitly inherent with the element of onrechtmatigedaad. However, it should still be considered that the element of authority/competence abuse refers to a species of the genus of onrechtmatigedaad, and the qualification of the element set in article 2 and 3, Law No. 31/ 1999 Jo. Law No. 20/ 2001 on Eradication of Corruption must be addressed based on the key element (bestanddeel delict) as mentioned in each of the articles. It is not generalizable that every action against the law with mutatis mutandis is either authority abuse or competence abuse.

Defining the term "competence" as a right and "authority" as a power as set in Law No. 30/ 2014 on Government Administration is not contradictory with the meaning of bevoegheid within the concept of administrative law. The interpretation of the term "competence" as rights is the basis of "authority" defined as power. Borrowing terms from private law coupled by the term "obligation" as the meaning of "tasks", power containing "tasks" within and law-based "competence" (rechtskracht) recognizing the term "right" and "obligation" (rechten een plichten) may generate the term "authority" or "competence". Thus, both the authority and the competence adhere to right and liability set under the law. Without any right and obligation, no power will be legitimized by the law. Therefore, law-based power is derived from tasks and authority or competence which contains right and obligation of law within. This interpretation is consistent with article 17 jo Article 20 jo Article 21 Law No. 30/ 2014 on Government Administration. Thus, instead of using the term 'testing on authority abuse', it will be more reasonable to use the term 'testing on competence abuse.' An authority abuse in Law No. 30/ 2014 on Government Administration is categorized into the competence abuse as well. Therefore, when the competence abuse is found occuring, the authority abuse mutatis mutandis is considered exist as well. Thus, it will be impossible to see authority abuse without any competence abuse within.

Therefore, it shows that the domain of testing an authority abusen refers to the domain of Government Internal Control Apparatus (APIP) and/or the competence of PTUN as set in article 20 and 21 Law No. 30/ 2014 on Government Administration. Furthermore, the argumentation claiming that testing an authority abuse does not refer to the domain of Government Internal Control Apparatus (APIP) and/or the competence of PTUN is considered as a sophism.

In article 20 subsection (1) and article 21 subsection (1) Law No. 30/ 2014 on Government Administration, both have asserted that Government Internal Control Apparatus are assigned to control the abuse of the competence, and the administrative court is assigned to test whether or not the element of competence abuse exists. Therefore, both the term "authority abuse" and "competence abuse" are categorized into one single concept and have no significant difference. If a different idea and interpretation exists between those two term (i.e., 'authority abuse' and 'competence abuse') and strictly considers the difference by relying them on article 20 and article 21 Law No. 30/ 2014 about Government Administration and then sees them harmoniously or has nothing to do with the key element (bestanddeel delict) in article 3, Law No. 31/ 1999 Jo. Law No. 20/ 2001 on Eradication of Corruption, such idea and interpretation may annul and ommit the likelihood of the process of testing dealing with whether or not the element of "competence abuse" -in which the element is considered as a key element in the implementation of article 3 Law No. 31/ 1999 Jo. Law 20/ 2001 on Eradication of Corruption- exists as set and mentioned under the article 21 Law No. 30/ 2014 on Government Administration. That idea and interpretation are identified as a misconception which is classified into a sophism and fallacy. Thus, in qualifying the key element of "authority abuse" as set under the article 3 Law No. 31/ 1999 Jo. Law No. 20/ 2001 on Eradication of Corruption, the law enforcement by the apparatus do not provide any difference between the two terms and even consider 'authority abuse' as 'competence abuse' which is categorized into the concept of 
administrative law. Therefore, verification on 'authority abuse' is characterized into State Administration domain When the element of 'authority abuse', which is considered as a key element (bestenddelen delict) set in article 3 Law No. 31/ 1999 Jo. Law No. 20/ 2001 on Eradication of Corruption, is not verified yet and not associated with the concept of 'competence abuse' set in Law No. 30/ 2014 on Government Administration, it indicates that the likelihood of unverified element may still exists but it has been considered as delict. Such act is categorized into criminalization which is not supposed to happen in law enforcement. Therefore, the apparatus should see the concept of the administrative law positively; particularly for the sake of law enforcement in relation to corruption. Given that the element of "authority abuse" is one of the key elements mentioned in article 3, that element must be firstly verified by providing rights and opportunities for a government official who is suspected conducting corruption to prove that he does not do any abuse of authority through evidence, as set under the article 21 subsection (2) Law No. 30/ 2014 on Government Administration, so that it may reach a fair and humane law enforcement (due procces of law).

In addition to that, a systematical approach is necessary to enforce the law, in particularly to interpret and comment on legal elements set in legitimate regulation. That is, it needs to interrelate each of the regulations in order to enforce and interpret the elements of law. When it comes into corruption issue considered as the element of an authority abuse, qualifying that element should be associated to the concept of administrative law since it is highly related to a function (ambts), while the concept of function refers to the subject matter of the administrative law. Thus, it should not be defined and interpreted separately.

Therefore, it is reasonable that interrelating the legitimate regulations may not be negatively understood as an attempt to decelerate/suspend and debilitate on handling corruption cases which potentially lead to a state into financial loss. However, it is considered as a part of law the enforcement process with the principle of due process of law which enforces defendant/suspect's rights, enforces the presumption of innocence and sees the suspected/defendant as a subject (accusatoir), thus, it may establish the assurance of law and a fair justice in a law state through a fair legal process.

If carefully seen, no comprehensive written explanation (lex scripta) on "authority abuse" is mentioned in the criminal/ the common law, thus, it generates multiple interpretations in the legal practices. Without using a systematical interpretation by borrowing the essence of "competence abuse" in the concept of the administrative law set under the Law No. 30/ 2014 on Government Administration, the implementation of article 3 Law No. 31/ 1999 Jo. Law No. 20/ 2001 on Eradication of Corruption, qualifying the element of "authority abuse" which is identified as the key element (bestanddeel delict) may turn into obscure libels. Thus, a subjective interpretation based on the law enforcer's perspective is likely to be imposed. Therefore, verifying the existence of "authority abuse" element related with the governmental function in order to qualify the element set in article 3, Law No. 31/ 1999 Jo. Law No. 20/ 2001 on Eradication of Corruption should use the principle of lex priori specialis as mentioned in Law No. 30/ 2014 on Government Administration, and when it is not firstly verified, the likelihood of filed lawsuit and prejudgment to can be null and void may happen.

\subsection{Theory of Authority and Competence in Administrative Law}

Etymologically, the essence of 'authority' and 'competence' is not significantly different. Generally, both 'authority' and 'competence' are classified into "authority" and in Dutch, it refers to "bevoegheid". Authority, in Black's Law Dictionary $(1990,321)$, in defined as "Legal power; a right to command or to act; the right and power of public officers to require obedience to their orders lawfully issued in scope of their public duties". Broadly speaking, it refers to a legal power; a right to reign or act; public officials' rights and obligation to have people obey any legitimate rules they established in the scope of their functions.

In a legal concept, 'competence' refers to a power derived from rights set by the law, as several liabilities/obligations are attached within those rights as well (rechten en plichten). In regard to these rights and liabilities, Nicolai argued, "Een recht houdt in de (rechtens gegeven) vrijheid om een bepalde feitelijke handeling te verichten of na te laten, of de (rechtens gegeven) aanspraak op het verichten van een handeling door een ander. Een licht impliceet een verplichting om een bepaalde handeling te verrichten of nate laten", Indicating that rights contain a freedom to do or not to do particular actions or get other parties to do particular actions, however, obligations contain liabilities to do or not to do particular actions.

Therefore, power refers to competence acquired based on rights and obligations set by the law (bevoegheid van rechtmatige). Legitimized power (rechtskracht) derives from law-based competence (bevoegheid van rechtmatige). A legitimate action is considered as a part of the legal order or having a legal power when it is based on the competence. That is, the competence may affect the law association after it is considered legitimate, and thus the government's measure may have a legal power. 
Competence is abstract in nature when it is not actualized into real actions. Authority is an actualization of the competence into real/concrete actions. Thus, authority is an active form (in concreto) of competence. Authority may not exist without any competence. Theoretically, therefore, no difference is identified between authority and competence, since the meaning of 'authority' and 'competence' conceptually refers to bevoegheid.

H.D. Stout $(2002,72)$ argued, "Bevoegheid is een begrip uit het bestuurlijke organisatierecht, wat kan worden omschreven als het geheel van regels dat betrekking heft op de verkrijging en uitoefening van bestuursrechtelijke bevoegdheden door publiekrechtelijke rechtssubjecten in het bestuursrechtelijke rechtsverkeer", Indicating that competence is a term derived from the law of the governmental organization and can be identified as the overall rules in regard to the acquirement and the usage of the government's competence by the subjects of the public law in relation with the public law.

Furthermore, F.P.C.L Tonnaer $(2006,265)$ asserted, “Overheidsbevoegheid wordt in dit verband opgevat als het vermogen om positief recht vast te stellen en aldus rechtsbetrekkingen tussen burgers onderling en tussen overheid en te scheppen". It indicates that competence is considered as a capability to conduct positive law, and thus, may create the legal relationship between the government and the public/civil.

Each of state and/or reign organization (staat in beweging) must be based on a legitimized power (rechtskracht) in the form of the legitimate law-based competence (bevoegheid van rechtmatige). Ratio legis from rechtmatigeheid van bestur generally known as legalization is a law-based competence (bevoegheid van rechtmatige). Either authority or competence has a fundamental function in a review of administrative law as F.A.M Stroik dan J.G Steenbeek $(2007,101)$ argued, "Het begrip bevoegheid is dan ook een kernbegrip in het staats-en administratief recht", which indicates that there is no either theoretical or conceptual difference between authority and competence.

\subsection{Legal Consequence of Authority and/or Competence Abuse by The Government}

The Republic of Indonesia constitutionally follows the principle of "law state" as set under the article 1 subsection (3) the Constitution 1945. The concept of dynamic law state is used as means of achieving the state's goals in establishing the justice and the people's welfare leading to become a welfare state. However, it leads for several plausible consequences covering various broad tasks for the government of Indonesia. Talking about those broad tasks, it is inseparable with the government functions, since such tasks refer to the government's obligations which need to be completed, while functions refer to the government's liability to achieve the expected goals. In order to complete the overall tasks and to achieve the goals based on the authority and competence within the administrative law, the nature of the government's authority and competence may have similar intention when attributed to the Law No. 30/ 2014 on Government Administration. It should be theoretically and conceptually understood that 'competence', as rights, and 'authority', as power, are both interrelated, that an authority contains right and obligation (rechten een plichten) which will turn to law-based power (rechtskrcaht). Therefore, 'authority' is considered as a legitimate power (rechtskracht) containing rights and obligations set by the law. Authority is a concrete form (in concreto) in actualizing a competence which is abstract (in abstracto) in its nature, hence, either the term 'competence' or 'authority' is used equally with the term bevoegheid in the concept of the administrative law.

Overall, it clearly shows that no different legal consequence is identified when the term 'authority abuse' is also considered as 'competence abuse' in the concept of administrative law and it will later be banned in the implementation of governmental functions, as mentioned in article 17 subsection (2) Law No. 30/ 2014 on Government Administration, as follow.

a. The ban of exceeding competence: The government officials and/or institutions are considered as exceeding their competence if the decision and/or actions they do: 1) exceeds the tenure or expiration of the authority; 2) exceeds the scope of the authority; and/or 3) conflicts with the regulation.

b. The ban of confounding competence: The government officials and/or institutions are considered as confounding their competence if their decision and/or action: 1) is beyond the scope of their authority's subject matter or material given; 2) conflicts with the purposes of their authority.

c. The ban of being arbitrary: The government officials and/or institutions are considered as being arbitrary if their decision and/or actions: 1) is without considering the principle of authority; and 2) conflicts with the court's judgment which is legally binding.

In philosophical context, the enactment of Law No. 30/ 2014 on Government Administration is an attempt to achieve a better governance and to prevent any possible corruption, collusion, and nepotism in organizing the government. The preventive action, in adagium context, is better than repressive action (penalization) so that any 
abuse of authority, opportunity, or functional tools may not happen in the process of organizing the governmental system, as set under the Law No. 31/ 1999 Jo. Law No. 20/ 2001 on Eradication of Corruption. Therefore, the concept of preventive action should not be confounded with the concept of the repressive action (penalization). In addition to that, the preventive action is not solely conducted by the repressive action. When the law enforcement confounds those two concepts -preventive and repressive actions-, either criminalization or even over-criminalization is likely to happen against the government officials and/or institutions by using the instrument of criminal law as an ultimum remidium means (ultimate weapon). This seems reasonable since an authority abuse may potentially bring the state into loss. Thus, corruption is considered as white collar crime which refers to an extraordinary crime.

If carefully viewed, a shift has already occurred on the function and scope of prevention in the corruption law enforcement in Indonesia, in which it seems overriding the function of the preventive actions, particularly in internal area assigned by Government Internal Control Apparatus (APIP) and/or the function of State Administrative Court (PTUN) which functions as means of control the government's actions, as set in article 20 and 21 Law No. 30/ 2014 on Government Administration. This function is responsible to assess whether or not any abuse of authority, which causes financial/economy loss, is likely to exist with an assumption that a repressive action is better in preventing any abuse of authority for the sake of organizing the good governance. Furthermore, studies related to the state's loss or the state's economy due to maladministration and/or abusing an authority are necessary to conduct. When the loss is not due to either the maladministartion or abuse of the authority, the element of the corruption-act is not verified. Although corruption does not always lead the financial loss against the state, it may happen due to gratification on public servants/the state enforcers/judges/attorneys as mentioned in article 4, 6, 11, and 12 Law No. 31/ 1999 jo Law No. 20/ 2001 on Eradication of Corruption. However, any financial/economy loss due to the maladministration and/or the abuse of the authority should be profed as the key delict (bestanddeel delict) in the implementation of the article 2 and 3 , particularly in the material context. In addition to that, it also aims to assess whether or not the element of foul exists since, basically, there will be no crime without any foul (geen straf zonder schuld). It is the principle of the common law followed in the Civil Law system.

One preventive way set under the Law No. 30/ 2014 on Government Administration is monitoring the ban of abusing authority/competence as mentioned in article 17 and 18. Such obligation is assigned to Government Internal Control Apparatus (APIP) in order to assess the government's administrative measures and/or decisions. The monitoring by APIP can be in the forms of:

a. No foul: If the result of monitoring by APIP does not find any foul, the principle of presumptio iustae causa, which refers to decision and/or correction on the decision and/or government's previous actions, will be applied.

b. Administrative foul is found: If the result of monitoring by APIP finds any administrative foul, a legal liability may emerge in order to complete the administration in accordance to the legitimate regulation.

c. Administrative foul which causes the financial loss for the country is found. If the result of monitoring by APIP finds any administrative foul causing the financial loss against the country, a legal liability may emerge to take back any financial loss in no more than 10 days since the result of monitoring is published. Indemnity is charged to the government institution when the administrative foul happen due to the element of authority abuse. That is, if any action leading to administrative foul which causes the financial loss to the country is not due to authority abuse as mentioned in article 17 Law No. 30/ 2014 on Government Administration, the liability of the indemnification is put upon the government body (institution/instance/function). However, for any action containing the abuse of the authority within as mentioned in article 17 Law No. 30/ 2014 on Government Administration, the liability of the indemnification is personally borned against the government officials.

Assessing whether or not any abuse of competence exists in the implementation of governmental functions by the Government Internal Control Apparatus (APIP) is mentioned in the article 17 Law No. 30/ 2014 on Government Administration. However, it seems necessary to apply due process of law in law enforcement to reach the assurance of law which keeps enforcing the human rights, so that the suspected can be seen as subject (accusatoir) and considered not guilty and has presumption of innocence. The Supreme Court Regulations of the Republic of Indonesia No. 4/ 2015 on Procedural Guidelines on Assessing the Element of Authority Abuse asserts that the government officials and/or institutions, for the sake of implementing the function of the good governance in the government area, are allowed to make a written request to the State Administrative Court in order to assess whether or not the element of authority abuse conducted by the government officials and/or 
institutions exists. Similarly, the article 21 Law No. 30/ 2014 on Government Administration also mentions that the government officials and/or institutions that feel disadvantageous by the result of Government Internal Control Apparatus may file a lawsuit to the State Administrative Court (PTUN) in order to assert whether or not the element of authority abuse exists in their decision and/or measures. In this case, PTUN has competence to accept, investigate, and decide the assessment of request whether or not the abuse of authority exists after the result of monitoring by APIP is published. Therefore, in no more than 21 days since the request is filed, the State Administrative Court must decide the request. The only legal action possibly conducted by the interested party is making an appeal to the State Administrative High Court that is liable to make decision in no more than 21 days since the appeal is filed. Furthermore, the judgment of the appeal is final and binding.

Therefore, it is clear that in the concept of the administrative law, no significant difference is found between "authority abuse" and "competence abuse". Abusing authority (detournement depouvoir) and/or being arbitrary (willekeur) is aligned with maladministration which is one action against the law by the ruler (onrechtmatige overheidsdaad) and it will be tested based on the general principles of good governance (algemene beginsellen van behourlijke bestuurs). Thus, any government's measure and/or decision implying particular action against the law (onrechtmatige overheidsdaad) will be considered as a legal defect or juridical defect which includes defects on the competence, the substance, and the procedures. Thus, it may turn the decision and/or legal action into null (vernietigbaar) or null and void (vanrechtswege nietig).

Following the concept of the administrative law, the abuse of authority or competence in government system is always paralleled with the concept of de'tournement de povoir. verklarend woordenboek openbaar bestuur constructs:

"Het oneigenlijk gebruik maken van haar bevoegheid door de overheid. Hiervan is sprake indien een overheidsorgaan zijn bevoegheid kennelijk tot een ander doel heeft gebruikt dan tot doeleinden waartoe die bevoegheid is gegeven. De overheid schendt aldus het specialitietbeginsel" (The competence is not properly used. In this case, the official uses his authority for particular purposes deviating from the original purposes. Therefore, the official is considered violating the principle of specialty." (Latif, .35)

Based on that concept, in assessing the existence of authority abuse, it should be factually profed that the official indeed has abused his authority for personal purposes. The abuse of the authority is not due to his negligence (culpa), but instead, his deliberately (dolus;opzet) shifts the given purposes adhered within his authority. It is based on his personal interests, either personal or for the sake of other's interests. On the contrary, there will be no abuse of the authority when no evidence of shifting purposes is found. The abuse of competence in the government system implies on the government authority or inherent power, either bounded, facultative, or free authorities (fries ermessen).

In the context of the law enforcement, a measure conflicting with the principle of legality and several principles contained in the law enforcement may possibly happen. Thus, the law enforcement may possibly not be in line with the primary purpose of law, justice. In order to achieve the purposes of law, the use of the instrument of the common law (penal) does not solely focus on the principle of ansich legality but also considers the principle of the proportionality and the subsidiarity, since they may emasculate the government officials in implementing their functions containing free, bounded, and facultative authorities within. Criminalization or over-criminalization on authority abuse conducted by the government official without firstly verifying the evidence may become a contradictory concept which opposes the provision set by the article 3 Law No. 31/ 1999 jo. Law No. 20/ 2001 on Eradication of Corruption. Criminalization also creates an impression of seeking for the public officials' foul and then makes them as the target of crime. If it is not recognized and prevented, such concept may impact the creativity of the government officials, who are considered as policy makers in implementing the functions of the public services. For instance, the creativity on economy aspect points to the dull of the state-owned companies' competitiveness (BUMN/BUMD) since it is worried that the policy established will be criminalized and categorized into the abuse of the authority (detournement de povoir) and/or the arbitrary action (willekeur).

The Indonesian presidents' policy under Presidential Instruction No. 1/ 2016 about the Acceleration of National Strategic Projects has encouraged the government officials' courage to act based on their creation in accelerating the enforcement of the national strategic projects. Thus, this Presidential Instruction is considered as President Joko Widodo's efficiency and responsiveness $(2016,4)$ against the ministers of Work Cabinet, the attorney general, the chief of police officers, the secretariat of the cabinet, the chief of presidential staff, the head of non-ministerial government institution, the governors and the local officials.

The emphasis of this presidential instruction on the law enforcement is refer to the attorney general as the case 
controller (dominis litis) in the criminal cases. One of the concerns is prioritizing the government administration process based on Law No. 30/ 2014 on Government Administration before conducting the investigation on the public report related with an authority abuse in enforcing the national strategic projects. The regulation is adopted from the principle of Economic Analysis of Law through Cost and Benefit Ratio in accordance to Richard A. Posner's idea (2004, 3-4). In its development, Robert Cooter \& Thomas Ulen $(2005,30)$ initiated an economic approach to solve the legal issues. They argued that the law is not solely about the juridical technical issues. More than that, it may positively imply on broader social purposes. This approach is a solution for guilt/punishment effects which seems not efficient/match with the expenses and impacts that reveal during the case proceeding, while particular preventive ways can be conducted in prior as mentioned in article 20 Law No. 30/ 2014 on Government Administration.

In his paper entitled Restorative Justice and Responsive Regulation, John Braithwaite $(2005,29)$ described the concept of responsive regulation, which assess to what extent of one's faults due to his will can still be pardoned without having to go through the prosecution and the penalization, as long as he has a good faith to admit his fault and is willing to do self-introspection. In this case, the instrument of the penalization is applied as the last efforts and the tools of curative measure that relies on the principle of restitutio in integrum, and not seen as merely giving sorrow which carry out such a traumatic syndrome for the government officials in organizing their function as the public servant (bestuurzorg). Instead, it is considered as a recovery effort to be as before.

Thus, Andhi Nirwanto's argument $(2-015,17)$ which differentiates the term 'competence abuse' and 'authority abuse' may lead to a legal consequence implying that Government Internal Control Apparatus (APIP) has no competence to conduct investigation on each of the government official's decision and/or action which is considered containing the abuse of authority in it as mentioned in article 20 Law No. 30/ 2014 on Government Administration, and furthermore, the State Administrative Court has no competence to accept, to investigate, and to judge whether or not any abuse of the authority is conducted by the particular government official, as mentioned in article 21 Law No. 30/ 2014 on Government Administration.

Besides that, such argument may also ommit the parameter in qualifying a ban of conducting any authority abuse as mentioned in article 17, 18, and 19 Law No. 30/ 2014 on Government Administration, since these regulations set the ban of abusing any competence in conducting the government functions.

A paradigm which differs 'authority abuse' from 'competence abuse' shifts the competence of the courts that examine the cases on the authority abuse. In this case, the abuse of authority is filed to the public courts and/or the corruption courts, while both the term 'authority abuse' and 'competence abuse' are considered similar since those relates with the authority of the governmental functions and the examination of those cases is included into the competence of the State Administrative Courts. Thus, the argument indirectly separates the concept of criminal law related with Law on Eradication of Corruption with the concept of the administrative law related with Law on Government Administration. Therefore, the perspective of the administrative penal law or the verwaltungs strafrecht as an entry point (raison d'etre) of the state financial loss is now considered as one element of the criminal acts of corruption and can be used as supporting means to enforce the legal norms related to the criminal acts of corruption, money laundry, and other criminal acts in order to do public welfare offense. Borrowing from Latina adagium in an Ancient philosophy which stated, "bene diagnoscitur, bene curatur" an appropriate diagnose or interpretation may result in good handling/cure-, the interpretation and the understanding on a regulation is fundamental in order to handle a legal issue, and it should relate with the theory and the concept of law which is not supposed to be seen in letterlijk gramatikal wet, so that it may prevent the emergence of any possible fallacy and misleading derived from misconception.

\section{Conclusion}

In the concept of administrative law, the term 'competence' and 'authority' both have similar conception and no significantly different. Therefore, the term 'authority abuse' and 'competence abuse' rely on one single concept related with the government function. An idea that differs the concept of 'authority' vs. 'competence' and 'authority abuse' vs. 'competence abue' without relating them with the concept and the theory of bevoegheid in administrative law can be disqualified and considered as a sophism since it contradict with the soul of Law No. 30/ 2014 on Government Administration as an attempt to prevent and minimize any possible maladministration in organizing the governmental functions.

The term 'authority' and 'competence' in administrative law are defined as bevoegheid. Thus, the interpretation of the Law No. 30/ 2014 on Government Administration mentions that the term 'competence' is considered as 'rights' which becomes the basis of 'authority', considered as 'power', and it is legitimized by the law (rechtskracht). The interpretation is consistent with the definition of the term 'authority' and 'competence' 
(bevoegheid) on the concept and the theory of administrative law. Therefore, there are rights and obligations (rechten een plichten) that should be conducted within the authority of governmental functions.

Differenciating the concept of 'authority' from 'competence' is a kind of separating the concept of law associated with the abuse of authority as mentioned in article 3 Law No. 31/ 1999 jo Law No. 20/ 2001 on Eradication of Corruption which, indeed, becomes the key delict (bestanddeel delict) in the concept of criminal law, and may cause criminalization or even over criminalization against the government officials with no proof by using the article 3 Law No. 31/ 1999 jo. Law No. 20/ 2001 on Eradication of Corruption without previously investigating whether or not any abuse of competence exists based on article 17 Law No. 30/2014 on Government Administration, and then it will be monitored by the Government Internal Control Apparatus as set under the article 20 Law No. 30/ 2014 on Government Administration, and it will be examined by the State Administrative Courts as mentioned in article 21 Law No. 30/ 2014 on Government Administration.

The separation between the absolute competence of the State Administrative Courts in examining a 'competence abuse' and the absolute competence of the Courts of Criminal-Act of Corruption in examining an 'authority abuse' which is considered as a key delict (bestanddeel delict) in article 3 Law No. 31/ 1999 jo Law No. 20 on Eradication of Corruption may lead the law enforcement to be inconsistent, unfair, and shifting the presumption of innocence to the presumption of guilty, so that the law enforcement in Indonesia may not be consistent with the principle of due process of law.

\section{References}

Andrea, F. (1983). Kamus Istilah Hukum: Belanda-Indonesia. Bandung: Cambodja. Ltd.

Black, H. C. (1990). Black's Law Dictionary. St. Paul.M.N: West Publishing.

Braithwaite, J. (2003). Restorative Justice and Responsive Regulation.New York: Oxford University Press.

Cooter, R., \& Ulen, T. (2004). Law and Economics. Boston: Person Addison Wesley.

Fachruddin, I. (2004). Pengawasan Peradilan Administrasi Terhadap Tindakan Pemeintah. Bandung: Alumni.

Friedman, W. (2010). The State and Rule of Law in a Mixed Economy. London: Steven and Sond.

Ridwan. (2002). Hukum Administrasi Negara. Yogyakarta: UII Press.

Hutchinson, T. (2009). Researching and Writing in Law. Australia: Lwbook Co. Pyrmont NSW.

Iqbal, Moch. Saleh, Khaerul, \& Sugiarti, M. (2014). Kriminalisasi Kebijakan Pejabat Publik. Laporan Penelitian Puslitbang Hukum dan Peradilan Badan Litbang Diklat Kumdil Mahkamah Agung RI. Jakarta.

Latif, A. H. (2014). Hukum Administrasi Dalam Praktik Tindak Pidana Korupsi. Jakarta: Prenada Media Group.

Marbun, S. F., \& Mahfud MD, M. (2011). Pokok-Pokok Hukum Administrasi Negara. Yogyakarta: Liberty.

Mahmud, M. P. (2009). Pengantar Ilmu Hukum. Jakarta: Kencana Prenada Media Group.

Mertokusumo, S. (2014). Perbuatan Melawan Hukum oleh Pemerintah. Yogyakarta: Cahaya Atma Pustaka.

M. Hadjon, Philipus. Effendie Lotulung, Paulus. Laica Marzuki, H.M. Sri Djatmiati, Tatiek. \& Gusti Ngurah Wairocana, I. (2012). Hukum Administrasi dan Good Governance. Jakarta: Universitas Trisakti.

M.Hadjon, Philipus. Soemantri, Sri. Basah, Sjachran. Manan, Bagir. Laica Marzuki, H.M. Berge, Ten J.B.J.M. Buuren, Van P. J. J., \& Stroink, F. A. M. (2012). Hukum Administrasi dan Tindak Pidana Korupsi. Yogyakarta: Gadjah Mada University Press.

M. Hadjon, \& Sri Djatmiati, Tatiek. (2008). Argumentasi Hukum. Yogyakarta: Gadjah Mada University Press.

Mulyadi, L. (2012). Bunga Rampai Hukum Pidana Umum dan Khusus. Bandung: Alumni.

Nirwanto, D. A. (2015). Arah Pemberantasan Korupsi Kedepan (Pasca Undang-Undang Administrasi Pemerintahan). Makalah dalam Seminar Nasional HUT IKAHI Ke-62. Hotel Mercure Ancol. Jakarta. 26 Maret

Sadjijono. (2011). Bab-Bab Pokok Hukum Administrasi.Yogyakarta: Laksbang Pressindo.

Seno, A, I. (2009). Korupsi dan Penegakan Hukum.Jakarta: Diadit Media.

Tonnaer, F.P.C.L. (1986). Legaal Besturen; Het Legalitietbeginsel. Kluer-Deventer.

Utrecht, E. (1986). Pengantar Hukum Administrasi Republik Indonesia. Surabaya: Pustaka Tinta Mas.

***Putusan Mahkamah Agung No 838K/Sip/1970; 
***Putusan Mahkamah Konstitusi No 21/PUU-XII/2014 tertanggal 28 April 2015;

***Putusan Mahkamah Agung Kamar Pidana Nomor 787 K/Pid.Sus/2014 tertanggal 10 Juli 2014;

***Putusan Mahkamah Agung Kamar TUN Nomor 263 K/TUN/2014 tertanggal 21 Juli 2014.

***Undang-Undang No 5 Tahun 1986 sebagimana telah diubah dengan Undang-Undang No 9 Tahun 2004 sebagimana telah diubah dengan Undang-Undang No 51 Tahun 2009 tentang Peradilan Administrasi (Lembaran Negara Republik Indonesia Tahun 2009 Nomor 160, Tambahan Lembaran Negara Republik Indonesia Nomor 579);

***Undang-Undang No 31 Tahun 1999 sebagaimana telah diubah dengan Undang-Undang No 20 Tahun 2001 tentang Pemberantasan Tindak Pidana Korupsi (Lembaran Negara Republik Indonesia Tahun 2001 Nomor 134, Tambahan Lembaran Negara Republik Indonesia Nomor 4150);

***Undang-Undang No 46 Tahun 2009 tentang Pengadilan Tindak Pidana Korupsi (Lembaran Negara Republik Indonesia Tahun 2009 Nomor 155, Tambahan Lembaran Negara Republik Indonesia Nomor 5074);

***Undang-Undang No 5 Tahun 2014 tentang Aparatur Sipil Negara (Lembaran Negara Republik Indonesia Tahun 2014 Nomor 6, Tambahan Lembaran Negara Republik Indonesia Nomor 5494);

***Undang-Undang No 30 Tahun 2014 tentang Administrasi Pemerintahan (Lembaran Negara Republik Indonesia Tahun 2014 Nomor 292, Tambahan Lembaran Negara Republik Indonesia Nomor 5601).

\section{Copyrights}

Copyright for this article is retained by the author(s), with first publication rights granted to the journal.

This is an open-access article distributed under the terms and conditions of the Creative Commons Attribution license (http://creativecommons.org/licenses/by/4.0/). 